\title{
French Tragedy during the Seventeenth Century: From Cruelty on a Scaffold to Poetic Distance on Stage $^{*}$
}

\section{Christian Biet}

Criticism, when it speaks of tragedy, generally has the goal of dissociating two terms: the tragic and tragedy as a genre. But, at the same time, critics are encouraged to see tragedy as a tragic way to represent people dealing with destiny, as Aeschylus did, as Shakespeare is supposed to have done, as Beckett shows us. Speaking of the tragic in tragedy is generally obvious as far as we admit, because we have seen in Nietzsche, or in Hegel before him, that the two terms can be put in the same basket: a tragedy is tragic, and the tragic is the first idea, the very first notion tragedy has to follow, because both of them are talking about destiny, and the position of man in front of God. That is the main stream of criticism, or at least, that was the main stream until we saw that in seventeenth-century France the majority of tragedies had nothing to do with this definition.

At the end of the sixteenth century and at the beginning of the seventeenth, when tragedy was a matter of death and blood, it took its examples from ancient history, from mythology and from current affairs (regicides-Henry III, Henry IV - or the violent deaths of prominent figures). Examples include Étienne Jodelle's (1532-1573) Cléopâtre captive (1553), which is considered as the first 'humanist' tragedy in French, and Didon se sacrifiant (ca. 1555), Robert Garnier's (ca. 1545-1590) Les Juives (1583) that took its subject from Biblical history, Cornélie (1573) and Marc Antoine (1578), both based on Roman history, and Hippolyte (1573), La Troade (1579) and Antigone (1580), with subjects taken from Greek history and mythology, as well as Jacques de Fonteny's (1587-1615) Cléophon (160o) and Claude Billard's La Mort de Henry le Grand (1610). ${ }^{1}$ At the

* I would like to thank Joe Johnson (NYU PhD student) for his comments and corrections.

1 For modern editions, see Étienne Jodelle, CEuvres complètes, ed. Enea Balmas (Paris: Gallimard, 1968); Didon se sacrifiant, ed. Jean-Claude Ternaux (Paris: Champion, 2002); Robert Garnier, Les Juifves, ed. Sabine Lardon (Paris: Champion, 1999); ed. Michel Jeanneret (Paris: Gallimard, 2007); Cornélie, ed. Ternaux (Paris: Champion, 2002); Marc Antoine, ed. JeanClaude Ternaux (Paris: Garnier, 2010); Antigone ou la Piété, ed. Jean-Dominique Beaudin 
start of this early modern period, when tragedy in France and all over Europe re-emerged on stage in a sort of re-birth, tragic theater became an alternative scenery for social action, a virtual scene for experimental lives, but also another judicial court for the audience, taking place inside theaters. At that point in time, the audience was spatially situated (and with more than $70 \%$ of the spectators standing in the 'parterre') in front of the stage, where it witnessed the cruelty, crimes and bloodshed often represented on stage.

\section{Tragedy as a Reenactment of the Cruel Atrocities of Recent History}

Yet we have to consider that at the end of the sixteenth and beginning of the seventeenth century France was trying to survive after a terrible shock and bloodshed of the wars of religion. Simultaneously Europe was trying to come to terms with what happened in Latin America (the genocide of the Indians), or even in England (the Wars of the Roses during the fifteenth century and their aftermath during the sixteenth). In France, for more than thirty years, the country had been immersed in horror: blood, rapes, lootings, and murders committed in the name of religion. 'Are the others more barbarians than we are?', asks Montaigne, thinking of the cannibalism that happened in Sancerre during the wars of religion and comparing it with the real and regulated cannibalism of the so-called barbarians or 'sauvages.' ${ }^{2}$ Literature and theater, then, had to grapple with and answer some urgent questions: was it possible to write after those absolute and massive crimes? Was it possible to play these stories and cases on stages? Was it possible to represent this terrible past? Just as Adorno and other philosophers of the twentieth century after Hiroshima and

(Paris: Champion, 1997); Christian Biet (ed.), Théâtre de la cruauté et récits sanglants en France ( fin Xvie-début du xviIe siècles) (Paris: Laffont, 2006) Collection 'Bouquins' (including De Fonteny's Cléophon and Billard's La Mort de Henry le Grand). See also, for instance, Gilian Jondorf, Robert Garnier and the Themes of Political Tragedy in the Sixteenth Century (Cambridge, Cambridge University Press, 1969); Raymond Lebègue (ed.), Les Guerres civiles de Rome et les tragédies de Robert Garnier: Actes du colloque de la Renaissance et du classicisme du Maine (Paris: Nizet, 1975); Phillip John Usher, 'Tragedy in the Aftermath of the Saint Bartholomew's Day Massacre: France's First Phèdre and the Hope for Peace', Romance Notes $5^{2}$ (2012), 255262; Christian Zonza, 'Le discours politique dans les tragédie de Claude Billard', Albineana, Cahiers d'Aubigné 22 (2010), 101-123; Donald Stone, French Humanist Tragedy: A Reassessment (Manchester: Manchester University Press, 1974).

2 See Jean de Léry, Histoire lamentable du siège de Sancerre, 1574, and Michel de Montaigne, Essais, first ed., 1580, chap. I, 31. 
the Holocaust, the 1590/1620's authors (and the spectators) had to face the acts of their fathers, had to confront their own acts or non-acts, their own crimes, their cowardice, the way in which they were only impotent witnesses, silent in the face of such massive bloodshed. At the same time, literature and theater had to consider their audiences, to reflect on the action or the non-action the people of this very audience had displayed a few years beforehand. How to write? How to represent? What? And where? The representation of that bloodshed will be in some instances on the stages, on the scaffolds, after the massive destruction which had been done by still living murderers, and seen by still silent people. This historical and moral situation is, for us, at once an ancient and extremely modern, contemporaneous, problem, and not only by way of analogy: the early modern period has something to say about our postmodernity.

It is generally acknowledged that Elizabethan drama inherits from Seneca its obsession with blood, cruelty and violence. It is less well-known in critical circles that French tragedies of the same period are also markedly 'Senecan', equally obsessed with violence and able to represent this violence directly on stage. ${ }^{3}$ In some respects, Elizabethan drama (as Shakespeare's Titus Andronicus and the tragedies of revenge from Thomas Kyd, Cyril Tourneur or John Webster) and the early French tragedies of the end of the sixteenth and beginning of the seventeenth centuries resemble each other to such a degree that they are almost identical in form and in subject, especially in their adoption of Senecan tragedy as a model-during this period, France was not as 'classical' as it would later become, if indeed French theater has ever been as classical as certain twentieth-century critics, who have their own understanding of the term, suggest. But if in Senecan tragedy we find a kind of equilibriumthe element of cruelty generally remains within the discourse, within the theatrical text-in this new tragedy everything (rapes, murders, etc.) can be on stage while the chorus provides a moral, political or didactic interpretation of the atrocities taking place in and off stage. As in other European countries

3 From Eliott Forsyth, La Tragédie française de Jodelle à Corneille, 1553-1640: Le thème de la vengeance, rev. and augm. ed. (Paris: Honoré Champion, 1994), and Raymond Lebègue, La tragédie française de la Renaissance (Brussels: Office de publicité, 1944, ${ }^{2} 1954$ ), some articles have been published on this topic. And lately, with Marie-Madeleine Fragonard and Fabien Cavaillé, Charlotte Bouteille-Meister, Corinne Meyniel, Sybile Chevallier-Micki, Tiphaine Karsenti, Mathilde Bernard, Michaël Meere, we are trying to re-discover this important corpus. See Sybile Chevalier-Micki, Tragédie et théâtre rouennais 1566-1640: Scénographies de la cruauté, Thèse de doctorat, Université Paris Ouest-Nanterre, 2013 (Paris: Classiques Garnier, forthcoming 2015). 
(Elizabethan drama for instance) crimes and punishments were at that time 'hyper-present' and 'hyper-performed', and at the same time theater created a sort of ceremony of remembrance in which the guilt of a community was witnessed, observed and analyzed by its members: tragedy was this ceremony, where memory was in charge of the revival story that was enacted in front of the public (and for the cruel moments, behind a tapestry at the back of the stage or, often, directly on the stage itself): Alexandre Hardy (1570?-1632) in Paris, Nicolas Chrétien des Croix and some anonymous playwrights in Normandy are the main representative authors of this period. ${ }^{4}$

The exhibition of the faults, of the mistakes and of the horrors took place in front of the people who had seen, lived through, or heard of terrible events before. In a sort of cathartic procedure, the audience saw the representation of guilt and had to judge the present of the representation and the past of the city.

These tragedies from the late sixteenth and early seventeenth centuries function as a sort of reenactment of the thirty years of civil and religious wars that troubled the second half of the sixteenth century. They were performed in the immediate aftermath of shocking violence and recent massacres to a still traumatized audience; and while, after thirty years of troubles, audiences may re-discover the pleasure of being inside a theater and being a part of this very particular social gathering in conditions of relative calm, these same members of the theatrical audience also discovered a new way of seeing, observing and commenting upon the violent acts of the bloody years of the wars of religion that derived from their representation on stage. This new theater, unconstrained by the (so-called 'classical') rules aspired to by a later age, left spectators free to comment on and judge its fictions. However, the spectators did not confine themselves to commentary, thus generally responding to whatever they saw and heard in a great hubbub of whistles and cries. It was as if the audience, three quarters of whom were standing in the pit while the remainder were seated in boxes or up in the galleries, had actively become a sort of chorus, responding to every remark, commenting on and discussing the action, creating a racket out of sheer enjoyment, for the pleasure of participating in this assembly.

It would appear, then, that the attempts of the crown to promote a politics of reconciliation and the activities of the theater are not really compatible. Even

4 See Biet (ed.), Théâtre de la cruauté et récits sanglants, where some of these tragedies are re-published and, for tragedies of martyrdom, see Christian Biet and Marie-Madeleine Fragonard (eds.), Tragédies et récits de Martyres en France ( fin XVIe-début XVIIe siècle) (Paris: Classiques Garnier, 2009). See also Bénédicte Louvat-Molozay, L'Enfance de la tragédie” (16101642): Pratiques tragiques françaises de Hardy à Corneille (Paris: Presses Universitaires de Paris-Sorbonne, 2014). 
if the kingdom and the king himself were espousing a policy intended to lead to reconciliation, or were attempting or claiming to do so, it was, at the same time impossible to escape the dreams of retaliation, vengeance and judgment still supported by the citizens of the kingdom. By performing bloody acts on stage and letting them be revived in the audience's feelings, theater tried to prevent the audience from materializing the cruel acts from stage in 'real action', but at the same time a risk still remained, leading to new disorders. What remained was an enduring fear: how could anyone prevent a recurrence of the wars of religion? This is why Henry IV of France, in the Edict of Nantes, set out in 1598 the legal requirement, following other similar ordinances or agreements, that his people should forget what had occurred and he did so in the very first two articles of the Edict:

(Henry, par la grace de Dieu roy de France et de Navarre) ... avons, par cest eedit perpetuel et irrevocable, dict, declaré et ordonné, disons, declarons et ordonnons:

I. Premièrement, que la mémoire de toutes choses passées d'une part et d'autre, depuis le commencement du mois de mars 1585 jusqu'à notre avènement à la couronne et durant les autres troubles précédents et à leur occasion, demeurera éteinte et assoupie, comme de chose non advenue.

II. Défendons à tous nos sujets, de quelque état et qualité qu'ils soient, d'en renouveler la mémoire, s'attaquer, ressentir, injurier, ni provoquer l'un l'autre par reproche de ce qui s'est passé, pour quelque cause et prétexte que ce soit, en disputer, contester, quereller ni s'outrager ou s' offenser de fait ou de parole, mais se contenir et vivre paisiblement ensemble comme frères, amis et concitoyens, sur peine aux contrevenants d'être punis comme infracteurs de paix et perturbateurs du repos public.

(We (Henry, by the grace of God King of France and of Navarre) have, by this perpetual and irrevocable edict, established and proclaimed and do establish and proclaim:

I. First, that the recollection of everything done by one party or the other, between March, 1585 and our accession to the crown, and during all the preceding period of troubles, remain obliterated and forgotten, as if no such things had ever happened. 
II. We forbid all our subjects, of whatever estate or quality, to revive its memory, to attack, resent, scold, or provoke each other with reproaches regarding past events, for whatever reason and on whatever pretext, to dispute, contest, quarrel, or to take umbrage or offence, in deed or word, but [command them] to contain themselves and live peacefully together as brothers, friends and fellow countrymen, on pain of punishment for those who contravene this order as disturbers of the peace and public rest. $)^{5}$

This policy of oblivion or forgetting in the name of reconciliation and harmony, ordered by royal decree, can be extended to actors and authors. But, as the regime in France was a monarchy (and not a totalitarian state), exceptions could be made, particularly for authors who wrote for the regime, especially those who were in the process of writing the history of the new Bourbon dynasty. It was however the reason why authors and actors who were generally forbidden by law to express their views on the recent past, even through a character or a role, and who were forbidden to portray this past (although it must be said that they sometimes did), ${ }^{6}$ employed the strategy of an historical or fictional 'detour' through ancient or medieval history or mythology. This enabled them to recount and represent on stage, for the benefit of their audience, the horrors of a very recent past that was still so vivid in the popular minds. And by these detours (through ancient history, or through a geographical estrangement), the recent past was shown. At the same time the authors employed the theatrical device of invoking the audience through a direct and personal address: by a performance, a philosophical, political and theatrical performance.

5 1598, Édit de Nantes. Édit général (see: http://elec.enc.sorbonne.fr/editsdepacification). The first article continues: 'Et ne sera loisible ni permis à nos procureurs généraux, ni autres personnes quelconques, publiques ni privées, en quelque temps, ni pour quelque occasion que ce soit, en faire mention, procès ou poursuite en aucunes cours ou juridictions que ce soit.'

6 As Charlotte Bouteille-Meister has recently demonstrated in her doctoral thesis, 'Représenter le présent: Formes et fonctions de l' actualité dans le théâtre en français à l'époque des conflits religieux (1554-1629)', Paris Ouest-Nanterre, 2011 (Paris: Classiques Garnier, forthcoming 2015). On Alexandre Hardy, see Fabien Cavaillé, Alexandre Hardy et le théâtre de ville français au début du XVIIe siècle (Paris: Classiques Garnier, 2015). 


\section{The Tragedy of the Scaffold}

Faced with the horrors of recent history, these 1590/1620s tragic authors were mainly taking the path of cruelty, excess, fury, as a mirror of the acts which had been just performed: this is how they interested their audiences. As the definition of 'tragedy' as a genre was not yet ruled by the notion of the 'tragic' that Hegel and Nietzsche proposed during the nineteenth century, the word 'tragic' often meant 'bloody': 'tragedy' was primarily understood as an enacted story about death and crimes, horror and guilt. This is the way the idea of the tragic was understood by the contemporaneous audience, and we can easily point to these tragic plays, linked to the end of the Wars of Religion, as being marked by historical catastrophe, an aesthetic and spectacular disposition of all the exceptional but possible transgressions man can perform.

Yet this sort of tragedy is not specific to the French stage: as 'baroque' tragedy it is also related to a larger aesthetical European movement where the representation of mankind, manners and actions has to be bloody, tragic both in theater and in prose stories. Fascinated by the wounds, the distress and the bloodshed, and at the same time able to think about the disposition of the actions and to interpret the violence of the former past as well as the present, European audiences could follow the verisimilitude of those times, after the real horrors the spectators have really experienced. The question for the playwright is not only how to represent excess, but to imagine with urgency a plot that copes with the memory people have of its past and of its present. To be seen, theater has to take place on an exceptional stage, recalling another exceptional place: the scaffold. To do so, the audience was located in front of the scaffold/stage which is above a standing parterre that is mobile, noisy, reactive, just like in front of a real scaffold.

We know that in those times the same word 'scaffold'-in French 'échafaud'-meant a scenographic system built to be easily seen, first for executions, but also for shows. The scaffold will never lose its first meaning: that of an elevated location easily seen, where there is a separation between the action and those who are witnessing the action. Everybody recalled, and simultaneously considered in the same time, that this system was both in reference to executions and plays: the échafaud is literally and virtually the location where people were killed or where deaths take place. On the judicial scaffold the executioner and his victim act the bloody parts of a real tragedy and the spectators know why there is an execution as they know the case. The execution is a ritual representing punishment by law, but also, the scaffold celebrates the way a criminal is going through expiation in order to be saved. Punished by society, confessed by the priest and forgiven by God, the convict, if he has a real contrition, can 
hope to be saved. On the scenographic system, death becomes a ceremony: judicial, social, and legitimated by law. On the theatrical scaffold, the audience can observe a bloody tragedy from the cause of the acts to the punishment, arriving at the conclusion by way of the criminal action. Those two scaffold ceremonies can lead the audience to be morally and religiously educated (the execution has to convince by example), but also to see the convict as a victim or a hero. In a sense, the medieval drama may never have been really absent, and the proximity between the judicial scaffold and the theatrical one is not yet a novelty. Jody Enders in Death by Drama and Other Medieval Urban Legends, or Jelle Koopmans and Marie Bouhaïk-Gironès have already noted this link during the medieval period. ${ }^{7}$ The way to enact the violent punishments in the Mystères or in the Passions can even be found in the numerous tragedies of martyrdom that the second part of the sixteenth century had produced.

The last possibility, of course, is that the audience might enjoy the spectacular suffering and bloodshed. If the crimes and the punishment were supposed to bring horror or pity, they brought several pleasures too: the pleasure to be with others to see what is going on, the pleasure to see the sacrifice, the pleasure not to be killed like the victim, the pleasure to enjoy the scene, and also the pleasure to judge that the convict is not guilty and that he/she is a sort of martyr or a hero. Those pleasures can be simultaneously felt. Taken by the strength of the striking effect or bloody effect, and caught up in the numerous feelings he can have, the spectator hesitates as to what reactions he can have and, simultaneously, is able to judge by himself what he sees. Staging of disorder, of contradictions, then of debate (usually judicial), then of the expression of mourning, grief, or of poeticized blame, and lastly, sometimes, the re-establishment of order and harmony, tragedy then represents on those scaffolds a critical and poetic reflection on the universe, power and the law, and after having transformed the contradictions into ambiguities. This allows the spectator (and the reader) to go back to the complexity of the case and

7 See Jody Enders, Death by Drama and Other Medieval Urban Legends (Chicago: The University of Chicago Press, 2002); among other publications: Jelle Koopmans, 'L' effectivité de la législation sur le théâtre: Le Parlement de Paris a-t-il interdit les mystères (en 1548)?', Cahiers de recherches médievales et humanistes 23 (2012), en Hommage à Jean Dufournet: Droit et pratiques théâtrales (XıIe-XVIe s.), 141-150; Marie Bouhaïk-Gironès, 'Introduction. Droit et pratiques théâtrales' and 'Le statut de l' acteur face aux pratiques du droit: L' exemple de l' affaire Poncelet au Parlement de Paris (1416)', Cahiers de Recherches Médiévales et Humanistes 23 (2012), 106-107; 127-140; Christian Biet and Marie-Madeleine Fragonard (eds.), Tragédies et récits de Martyres en France ( fin XVIe-début XVIIe siècle) (Paris: Classiques Garnier, 2009), see the bibliography and the notes. 
to criticize and judge it. If some desire for harmony or resolution often hangs over the plot (the persuasive effect of stability), the staging of confrontation, contradiction and ambiguity afforded, all at once, the release of a violent and long lasting emotion, a reflection on the means of representation, and finally a critical reasoning on the status of the questions raised by the tragic act. ${ }^{8}$

This is how tragedy will interest its spectators, and how these spectators will use their own judgment to determine, as the plot advances, the competence or incompetence of the sovereign, of the father and of the husband, of the legitimacy to which they aspire, and of the competence of the fictitious sovereign (public: the king, or domestic: the father) as it or he is compared to the current, real sovereign. For the purpose of tragedy and of tragicomedy is to show that judgment is not obvious, that it is difficult and therefore interesting as well as entertaining. It is thus critical that the spectator hesitate and pause, for a second, when he/she must evaluate an extreme and complicated case arising from a specific and violent conflict which the playwright has chosen as his subject and as his fable, a case the spectator will follow through its course. It is finally because there is extraordinary excess and an extreme representation of the world that there is interesting subject matter necessitating judgment, and it is because these excesses may appear unrealistic that they are put forth as examples by which to evaluate power, the law and its customs, because they grip the audience, because they move and because they shock it.

\section{An Aesthetic Shift to the 'Classical' Tragedy}

Although the idea of judgment and the architectural disposition (stagescaffold, $70 \%$ of the audience standing, etc.) remained more or less the same during the whole century (except that after 1637 between thirty to more than sixty spectators were regularly seated on the two sides of the stage itself), the aesthetics were changing. With the cultural and political actions of Louis XIII and Richelieu, ${ }^{9}$ theater could now be recognized as an 'honest' and useful

8 One could then see in this re-birth of tragedy, a type of response to what happened in Greece several centuries before. See, on this subject Emmanuelle Danblon, 'Du tragique au rhétorique', in Michel Meyer (ed.), Rhétoriques de la tragédie (Paris: Presses Universitaires de France, 2003).

9 See the Déclaration du Roy Louis XIII au sujet des Comédiens. 16 Avril 1641. Ordonnances enregistrées au Parlement, 8ème vol. de Louis XIII, Archives, coté G GG, fol. 234; and Christian Biet, 'Le lent dressage des publics de théâtre, l' avénement du théâtre dans le champ littéraire 
medium if its plays were 'honest' (i.e. becoming 'literary' and connected to the ideology and to the aesthetics of the forthcoming absolute power), if its actors were good citizens and if its audience was able to reject some individuals or groups who caused disturbances and damage inside the playhouse. Theater of seventeenth-century France was not, in the big cities, a 'popular theater' which mixes all the different social classes. Even at the 'parterre' (the standing places in front of the stage), the entrance was rather expensive (the price of two days' labor of an artisan). And as long as the playhouses became more selective and more 'honest' and 'civilized', a new 'taste' ('goût') emerged, more gallant, with an important feminine component, and literary concerns. Actually, we can notice a shift from the 1630 s and just before the middle of the seventeenth century: with Jean de Rotrou, Pierre Corneille and the other 'modern' authors such as Georges de Scudéry, theatrical French aesthetics were becoming 'classical'.10 The enactment of violence weakens, the new authors link back to the humanist theatrical tradition (Jodelle, Garnier), move away from Seneca's tragedies to get closer to Sophoclean and Euripidean models, and begin to read, translate and discuss Aristotle's Poetics. This does not mean that cruelty or blood had become absolutely forbidden, but just that they had to stay inside the discourse, inside the plot, and declaimed through a theatrical poem. If the main questions stayed the same - political and sentimental passions, libido dominandi, libido sentiendi, curiositas, sovereignty, auctoritas, tyranny, etc. - the way to represent them had to be different and suitable to the new aesthetics of tragedy: a tragedy which has to be noble and honest, even if theater knows how to remain critical and if conformity is not a blind compliance nor an absolute obedience to power. But before everything else tragedy was now to be poetry and speech, a spoken

(Xvire-XvıIIe siècles français)', in Donatella Pallotti and Paola Pugliatti (eds.), La guerra dei teatri: Le controversie sul teatro in Europa dal secolo sedicesimo alla fine dell'ancien régime (Pisa: Edizioni ETs, 2007) Università degli Studi di Firenze, Dipartimento di Filologia Moderna.

In this article, I will not insist on the opposition between 'baroque' and 'classicism' which I consider simplifying and, in a way, dangerous. If, during the first part of the seventeenth century, there is a shift that this present text tries to describe, in the way to think — with appropriate theories and a return to Aristotle-, to represent and to compose theater, I doubt that this shift can be summarised by a change of labels ('baroque' to 'classicism') that seventeenth century's theoreticians and authors did not even endorse. See Christian Jouhaud, 'The Notion of "Baroque": Polemical Debate and Political Issues in France', http://www.enbach.eu/en/essays/revisiting-baroque/jouhaud.aspx; and JeanPierre Cavaillé and Cécile Soudan (eds.), Les dossiers du GRIHL, La notion de baroque, approche historiographique, 2-2012, http://dossiersgrihl.revues.org/5057. 
poetic text, and less and less enacted actions. Everything would have to happen by means of poetic discourse, even the most violent actions, which, in general, were reported by confidants or messengers who borrow an epic style in order to relate a fight, a murder or a horrible action: think of Théramène's narrative in Racine's Phèdre (1677). More than a playwright, Jean Racine was a poet, and his auditors or readers recognized in him a charm and an evocative power that combined tenderness and intensity. Interest is thus sustained by speech and poetry, and the spectator's pleasure is supposed to come both from this speech and from the unfolding of the crisis.

This so-called 'classical tragedy', from ca. 1630 to the eighteenth-century in France, is thus a noble dramatic poetry and a noble plot in five acts, with noble characters, saying noble but simple lines (alexandrines), concerning noble or terrible goals: sovereignty, tyranny, the way a king is conducting his state, the way he resists his passions, the passions themselves (which can be devastating) and the means to cope with them by will, the place of the 'libre-arbitre'. If the play is announced as a tragedy, the audience knows that everything will be noble: characters, language, manners and stakes. This is the verisimilitude, which is understood as a contract: a king has to act, talk and behave as a king. That is why, too, bienséance, decorum are here: as the characters are noble, it is impossible for them (or it is a huge transgression for them) to perform nonnoble acts or to think non-noble ideas. In parallel, to guarantee the effects tragedy wants to have on the audience, the dramatic poem submits to rules. Far from binding the poet's imagination, these constraining rules have, from the beginning, the function of concentrating the emotions. Unities of place, time and action: the spectator's concentration must not be stopped. That is why, from ca. 1640, the authors and theoreticians assume that the audience does not want to be taken in several places, in several times, or by several actionsas we said, this is a return to Aristotle's Poetics, rediscovered by theoreticians and authors in France around 1635 and that l'Abbé d'Aubignac developed and updated in his Pratique du théâtre (1657). There is here a sort of contract: if the authors want the spectators to think about politics, passions and heroism, they have to fix their plot on one story only and to let their spectators think and have comfort in their pleasure; they must free them from observing different places in more than a twenty-four hour period. Thanks to this, the audience can follow the text, and can think and appreciate its complexities.

The subject of this type of play is usually borrowed from myth or history (mainly Latin history), rarely the Bible (especially for the 'college' tragedies, the tragedies written for and played in the (religious) colleges), rarely history of the Middle Ages, rarely contemporary history after the second part of the seventeenth century (but, as we have said, often before), sometimes oriental 
history (Racine's Bajazet (1672), for example, takes place at the Ottoman court of the sixteenth century), depicting renowned characters, heroes and kings and representing an action whose evident goal is, according to Aristotle 'to excite terror and pity by the spectacle of human passions and of catastrophes which are their fatal result': by this excitation of terror and pity, the tragedy is then supposed to lead the audience to a catharsis (a purgation, or an purification of the passions). If catharsis is, in this period, a notion that some theoreticians understand it from Aristotle's Poetics, for most authors of the seventeenth century, the idea is difficult. Some of them try to use the notion to bring terror and pity in a positive way - with terror and pity, tragedy fights negative passions (dangerous ambition, love passion, hate, jealousy)—, some forget and replace catharsis by admiration, and the rest think that terror, pity, admiration and even horror have to be discussed contradictorily on stage. Pierre Corneille assumed that admiration was the real passion tragedy has to give to the audience, and Racine tried to activate a Christian version of pity: compassion. But if there is a clear moralizing finality that tragedy had to endorse, which is to edify the public, this poetical and theatrical genre is also supposed to make the audience think, discuss and judge. Negative passions are presented before the eyes of the spectators to show all the disorder that they cause, but also to show them what important and fascinating notions they are.

\section{Dramaturgic Structure}

From the dramaturgic point of view, the conflict is at the heart of classical tragedy's plot, and the crisis opens with a conflict: a man's conflict among men, mostly, and sometimes a man's conflict with himself, much more even than with the gods. The 'risk of death' (a 'péril de mort') has to be inside its plot, a plot that can end well or finish in a real catastrophe, with some deaths at the very end. The tragedy begins in medias res, in the middle of the unfolding of the story: in Racine, the first scene often begins in the middle of a conversation (the first word is a response: 'Yes, ..., 'No ...'); generally at dawn (beginning of the twenty-four hours); in one place (a vestibule, a palace, 'at will'); a hero, most often, and a confidant discuss the situation and relate what has happened earlier, which allows the tragedy to orient itself to the crisis, which is the essential matter. The exposition scene must be quick, short, interesting and believable; it must concentrate the subject in order to give place immediately to the crisis. The following scenes (Nicolas Boileau, in his Art poétique (1674), wishes that the exposition lasts, at most, no more than two scenes) continue to present the action by making the main characters intervene (to slow down their 
arrival is thus an effect) and by complicating the action. After the exposition, tragedy can follow different methods. The first and main one (with Corneille for example) multiplies the obstacles, peripeteias and coups de théâtre; the obstacles arise in the course of the crisis that develops to the extent that they come to dominate, and the peripeteias are the unforeseen events that modify the hero's situation. During the second part of the century (with Racine) they are more or less forbidden for this 'noble genre', as they are external to the plot, would shatter the logic of it and thus become confused with tragicomedy. That is why the construction by degrees (step by step) is chosen by Racine. The plot, then, faces the ineluctable accomplishment of destiny. The playwright must see to it that a continuous tension is set up and that multiple effects determined by the rebounding of the action, now refused by the genre, be replaced by a concentration of the speeches on the peril of death. In this sense, Racine is in the modern 'tragic', but he is isolated. Both systems have the effect of dilating the action, of amplifying it, in the rhetorical sense of the term, by playing upon the retarding, the installation of dilemmas, the rhetorical reversals in the speech of a character (pro and contra) allowing a verbal amplification of the conflicts.

Then, the dénouement or the catastrophe is the final event that cuts the thread of the action by the suspension of the perils and obstacles. Misfortune is then generally consummated without, in many cases, grace having appeared. The denouement of a tragedy can be untragic (a tragedy with a happy ending) or can be deadly, but redoubled by a second ending that provides a result to the play (declaration, appearance or intervention of an external or innocent character who 'saves' the plot from absolute disaster).

\section{Tragedy Takes Place in Political Field: Behind the Clemency of Augustus}

Although this genre, during the seventeenth century, comes to be a constrained aesthetic code, it is at the same time a means to explore the possible transgressions of man and especially men and women of power. In Cinna, ou la clémence d'Auguste (1641) Pierre Corneille offers a good example: noble characters (an emperor of Rome, Auguste-Augustus-; noble men and women-Cinna, Émilie), noble lines, five acts. The play contains a noble plot and a noble goal representing the way for a tyrant to conquer a new legitimacy and to become a real sovereign. During the five acts, except the last scene, Octave, the former tyrant, has to face the disorder of a conspiracy (lead by Emilie and Cinna), and in the second part of the very last scene Octave becomes Auguste, a real 
sovereign, who knows how to forgive the former conspirators, and who initiates a new legitimate political order.

First of all and at a first reading, it could be easy to conclude that this tragedy corresponds perfectly to the idea of absolute monarchy. It begins with a crisis - the king wants to be a good king but he has to face conspirators coming from his difficult past - and ends with the beautiful gesture of the monarchthe man of power prefers to forgive than to punish. Using the Senecan $D e$ clementia, ${ }^{11}$ Corneille could be seen as an advocate of Richelieu and Louis XIII's politics. ${ }^{12}$ But going back to the play, it is also possible to understand that, as the text demonstrates, before the beginning of the crisis and before becoming Auguste, the emperor was named Octave and was a violent, illegitimate tyrant, established as an emperor by force, murder and villainy. ${ }^{13}$ If we follow this line, we see that Octave tries to resist a legitimate conspiracy leaded by noble enemies. The main question of the tragedy, then, changes. How, in all actuality, can Auguste become a legitimate sovereign when everybody knows that he is perhaps still a tyrant? And how can he prove a legitimate sovereignty? First answer: by showing the fact that he endorses the qualities of a real king: prudence, justice, force, and also clemency. Being prudent, using good justice, practicing clemency, Auguste then can conquer his legitimacy by forgiving Cinna and Emilie. He does that in a brilliant action, in one line and a half: 'I am master of myself as of the world; I am, I wish to be.' ('je suis maître de moi comme de l'univers, | Je le suis, je veux l'être', ll. 1696-1697), and with the decision of clemency: 'Cinna, let us be friends. This I entreat. As once, my enemy, I spared your life in spite of your insane and base design, I spare you, as my murderer, again.' ('Soyons amis, Cinna, c'est moi qui t'en convie: | Comme à mon ennemi je t'ai donné la vie, | Et, malgré la fureur de ton lâche destin, | Je te la donne encor comme à mon assassin.', ll. 1701-1704). ${ }^{14}$ With clemency, which is justice and prudence and a political coup (a 'coup d'État'), he shows that he is, now, a good sovereign, and thus Cinna, Emilia and Maximus will recognize the fact. The play can end. The new order of legitimate monarchy can reign.

\footnotetext{
11 Seneca, De clementia I, 9.

12 See John D. Lyons, The Tragedy of Origins: Pierre Corneille and Historical Perspective (Stanford: Stanford University Press, 1996), and Kingdom of Disorder: Theory of Tragedy in Classical France (West Lafayette, IN: Purdue University Press, 2011).

13 See Corneille, Cinna, ed. Christian Biet (pref., ann. and comm.) (Paris: Le Livre de Poche, 2003), Christian Biet, La Tragédie (Paris: Armand Colin, ${ }^{2} 2010$ ) Collection 'Cursus', and Georges Forestier, La Tragédie française (Paris: Armand Colin, ${ }^{2} 2010$ ).

14 Pierre Corneille, Cinna, ou la clémence d'Auguste, tragédie. 1643, ed. Christian Biet (pref., ann. and comm.) (Paris: Le Livre de Poche, 2003), acte V, scène 3, pp. 121-122.
} 
Yet at the same time we have seen what was behind the 'curtain of the state': if Auguste had been so absolutely clement, and so ideally absolute when he forgives Cinna and Emilie, it is also because he was told by Livia, his wife, during the fourth act, that clemency is the best way to win, and to earn his legitimacy. Entering behind the curtain of state, tragedy problematizes politics, shows the calculations and the ambiguity of absolute power. Even if Auguste is clement, even he is a good sovereign because he shows the virtue of clemency, even if he seems to be suddenly illuminated by grace and providence, anybody can read, or see, that it is also because he is a good politician and a good calculator helped by a Machiavellian woman who tells him to do so. Thus the question is, is he, at the end, a good sovereign or still a tyrant?

This is the interest of this Cornelian political tragedy: the audience can feel the ambiguity of sovereignty and can see what is hidden behind the curtain representing the beauty of the State ... We, the audience, can judge or decide. We have to interpret, to think, and take the necessary distance to evaluate these 'noble' matters.

\section{The Weakness of the King in Le Cid and Horace}

We could say the same thing about Le Cid, Horace, Sertorius, Othon, Cornelian plays, but also, of all these seventeenth-century tragedies, even Racinian ones. Le Cid and Horace for example, are two political moments (in their fictional worlds, but also in respect of when they are written, between 1636 and 1640) where the aristocracy hesitates between its own power and the concession of it to the absolute power of the absolute king. And we, the audience, are hesitating too, to condemn or to forgive the characters of aristocrats-exactly like the weak king does in these plays.

In Corneille's tragicomedy Le Cid (1637) Rodrigue fights in a duel Don Gomès (the father of the woman he loves, Chimène) because Rodrigue's father had been offended: it is thus an aristocratic duel forbidden by the crown and this is Rodrigue's first mistake. As a consequence of this, the king has to judge this fault, but does not have enough strength to render justice in front of the aristocratic party. Moreover he also does not have enough strength when his country is assaulted by the Mores. Hence, to recover a sort of judicial and political virginity, Rodrigue escapes the stage, fights the Mores with his own army, without the order of the king, triumphs like a hero with his own strength and becomes a brilliant general that the king has to consider and respect. Rodrigue saved the crown but he threatens it because he is, now, in a position to have more power than the king. Between heroism and rebellion, Rodrigue, once 
again, has to be judged. Not only because of these two political mistakes (the dual and the battle held without the king's order), but also because Chimène demands, requires a judgment on her case (the murder of her father, Don Gomès). As we can see, oscillations, hesitations, difficulties in arguing for one or the other of the options given by every character, are the dynamics of this play. Thus, at the very end of the tragedy, the king speaks, and forgives Rodrigue in the interests of an internal and political peace, and of the crown: 'Time often enough made lawful what first seemed to be without crime' ('Le temps assez souvent a rendu légitime | Ce qui semblait d'abord ne se pouvoir sans crime.'), says the king to Rodrigue, ll. $1839-1840 .{ }^{15}$ Rodrigue will be forgiven if he becomes a general under the king's power and sovereignty. All that ends well and the king speaks the law: 'Hope in your courage, hope in my promise, and having already the heart of your mistress, let time, your courage, and your King defeat a point of honor that fights against you' ('Espère en ton courage, espère en ma promesse, | Et possédant déjà le cœur de ta maîtresse, | Pour vaincre un point d' honneur qui combat contre toi | Laisse faire le temps, ta vaillance, et ton Roi', ll. 1863-1866, end of the play). ${ }^{16}$ But, at the same time he establishes a blackmail of sorts in order to submit and forgive the heroic aristocrat. Thus the audience have seen that the king had been weak, and that his weakness has something to do with the strength of his aristocracy. Moreover the audience has now to think that the king's power comes from his nobles and therefore the king has to forgive the betrayals of his nobles if he wants to reign in peace.

In Horace (1640), the question is almost the same since it examines how a king must forgive the murder in the name of the state of a sister by a brother in an aristocratic family, by an aristocrat who before saved the country: at the same time that it is a discussion of Aristotelian magnanimity, the play draws a debate on the legitimacy of the aristocracy to endorse and enact the values of the State. Horace is in fact a hyper-legitimate hero. In the first part of the play Tulle, the king of Rome, gave Horace the role of fighting for the State against Albe and the Curiaces, Horace prevails and saves the city (even if it is in a way, by deception). But then when Camille, Horace's sister, learns that her brother had killed Curiace, the man she loves, the crisis begins. Camille vehemently insults Rome and the state and therefore Horace, by himself and without an order, kills her. As he does this without an order or the permission of the king, once again,

\footnotetext{
15 Pierre Corneille, Le Cid, tragi-comédie, éd. 1637, ed.Jean Serroy (Paris: Gallimard, 1993) Folio Classique, Acte v, scène 7, p. 148.

16 Ibid., p. 149.
} 
we can see a hero saving the crown, acting to defend the name of the king, but betraying and threatening him because he acts for himself. The end of the tragedy will be the same: Tulle will forgive (he is not in a political position to do thing else) and at the same time he will say that Horace has to act under his power, which Horace accepts. 'Then live, Horace, live, you, too brave a warrior, your virtue puts your glory above your crime, your noble ardor has produced your crime, for such a good cause one has to suffer the outcome. Live to serve the state ...' ('Vis donc, Horace, vis, guerrier trop magnanime, | Ta vertu met ta gloire au-dessus de ton crime, | Sa chaleur généreuse a produit ton forfait, | D' une cause si belle il faut souffrir l' effet. | Vis pour servir l'État ...'), says Tulle, the king of Rome, to Horace in the last scene of the tragedy (ll. 1759-1763). ${ }^{17}$

The audience has seen what stands behind the curtain which covers the secrets of the state, and had the opportunity to observe the intentions which drive the acts of the kings, their passions, their calculations, their sovereignty analyzed on the stage itself; and these facts, presented in these tragedies are cases difficult to judge, ambiguous but interesting for the public. The distance between appearance (the power of the king) and the real (the weakness of the crown), between the brilliant actions of absolute power and the history behind it, with the calculations, the murders, the role of the passions, create a space of judgment, a possibility of thinking politics for the audience, and a space to understand what stands behind the sovereignty, the power, and the legitimacy.

\section{King's Passions in Racine's Tragedies}

Even Racine, in Britannicus and Bérénice, plays the same game, with different weapons. With him, the intimate passions are poetically verbalized in front of the public. The sovereign is held by his passions, and often overwhelmed by them. In Britannicus (1670), before the tragedy begins, Neron was becoming a good emperor: he had Seneca for a teacher and philosopher and was trying, as Agrippine his mother asserts, to escape his monstrosity. But with Seneca gone, Burrhus, a good but inefficient adviser, is weak in front of Narcissus, the bad adviser-a dangerous freedman. The crisis can happen: the first scene of the play shows Agrippine trying urgently to see her son and emperor, at dawn, in order to know what is going on. Neron, says Agripinne, is taken back by his heritage (his fate? his destiny?) and it seems that, seized by his ambitious

17 Pierre Corneille, Horace, 1641 , ed. Jean-Pierre Chauveau (Paris: Gallimard, 1994) Folio Théâtre, Acte v, scène 3, p. 118. 
passion (libido dominandi) he becomes a tyrant neglecting the former power of his mother. In fact, he ordered the imprisonment of Junie, who is a political threat to him. The libido dominandi of Neron is the first passion which appears, but, from this, he falls into another one: the libido sentiendi, a libido which involves him in an irresistible love passion. 'Spurred by a curious desire that night, I saw him arriving in these places, sad, raising to heaven his eyes wet with tears, that used to shine through torches and weapons, beautiful, unadorned in the simple device of a beauty that one comes to get in sleep ...' ('Excité d'un désir curieux | Cette nuit, je l'ai vue arriver en ces lieux, | Triste, levant au Ciel ses yeux mouillés de larmes, | Qui brillaient au travers des flambeaux et des armes, | Belle, sans ornement, dans le simple appareil | D'une beauté qu'on vient d'arracher au sommeil ...', ll. 385-390, Acte II, scène 2). ${ }^{18}$ He will confess to his adviser that, during the former night, he saw Junie amid the guards who were there to arrest her, in the twilight of the candles, almost naked, and from this vision, he conceived passion for her: the libido dominandi, political libido, leads him to libido of love, and then to jealousy, hate and murder.

The crisis has begun and the whole play will represent Neron's exercise of passion on Junie, Britannicus, and Agrippine. The audience sees an emperor, a king, overwhelmed by his passions, taken by desire, and the spectators must be fascinated by these transgressions. Hence the emotion the audience has for Junie and Britannicus, the two innocent heroes, is then compassion: the spectators are supposed to cry with the pathetic heroes, have pity for them, share their sufferings. On her side, Agrippine tries to see her son, succeeds, but fails to convince him to let her govern for his own sake. The audience observes her calculations, her ambiguous character, and hesitates between compassion and condemnation. Britannicus believes Neron and finally drinks Neron's poison. Junie tries to resist, cries, and finally escapes. And when Neron loses Junie, but not his own tyrannical power, in the end of the tragedy, the audience can observe and spy on the intimacy of the court, its failures and its tragedies. The spectator can be taken by the tears of Junie and by the dark sensation which is seen to be behind Neron: if the tears of Junie lead to compassion, they are, in the same time, a good way to fascinate. We know, and Racine knows, that an innocent woman in tears gives pleasure, and if it is the case for Neron, it is also the case for the audience-obviously, the pleasure of cruelty does not appears only with Sade ...

18 Jean Racine, CEuvres complètes, Britannicus, tragédie, 167o, ed. Georges Forestier (Paris: Gallimard, 1999) Pléiade, p. 389. 
Even if this tragedy is apparently moral, there is a space for something dark, something like a pleasure of evil inside its disposition and its plot. We are thus interested in seeing the intimacy of the kings not only to admire them, but also to understand that they are men like us, held by passions, indulging pleasures, and even acknowledging the evil they do ... Once more there is a distance, a moment for thinking, a place for interpretation and judgment, and a place for the (dark) passions of the characters, and also of the spectators ...

Bérénice (1670) shows the same phenomenon, but backwards: Titus's father has just died, and Titus automatically becomes the emperor. Hence, if he wants to become a moral sovereign, he has to change his life and abandon any 'divertissement'. He also has to leave Bérénice as an emperor (described as a French king) who is unable by law to marry a foreign queen. But if he still wants to marry Bérénice, he will be a tyrant. If not, he can be legitimate. The tragedy takes place in the very moment when the prince becomes an emperor, when a young man in love with a foreign queen has to forget his passion to be a complete king: this is the crisis, and the denouement will be, five acts later, when Bérénice leaves Rome and Titus. 'Be here a witness of all my feebleness' ('Soyez ici témoin de toute ma faiblesse'), says Titus at the last scene of the tragedy (ll. 1439). ${ }^{19}$ At the same time, the audience can observe, with tears and compassion, the way the king becomes a true king, the way he resists his passions, and the way Bérénice, in the end, helps him to do so. Once again the veil which covers the state is lifted and we see the man, his passions, his hesitations, and we hesitate with Titus. Once again, we have to consider the fact that power is fragile because it is held by a man, both weak and strong like we all are.

\section{Tragedy, Tragic and Distance}

We have seen with Corneille that admiration and observation of political contradictions are at the center of his interest. We have seen that compassion, tears, pathetic issues and observation of men's passions in the figure of the king are specific to Racine. But the dramatic notion and issue which is treated experimentally by both is also distance. A distance (not so far, for Corneille, from the distanciation—Verfremdungseffekt — that Brecht will theorize during the twen-

19 Jean Racine, CEuvres complètes, Bérénice, tragédie, 1671, ed. Georges Forestier (Paris: Gallimard, 1999) Pléiade, p. 506. 
tieth century) for the audience to think, to judge and to interpret, even though this audience feels admiration or compassion, even though the spectators are taken by a dark sensation of pleasure or seized by a beautiful sensation provoked by heroes. And if Corneille uses admiration, it is not to dazzle his public, not to give an absolute model to the spectators, but to build a case with concrete and abstract elements they can admire, observe and evaluate.

All those remarks might lead us to think that there is no tragic in Corneille's tragedies and in most of the tragedies of the seventeenth and eighteenth centuries: kings and heroes are fighting with other heroes and kings and against themselves, they are enacting politics. The audience, at a distance, can appreciate that these kings and heroes are noble, exceptional, but not exempt from human passions. Then, the historical situation, the circumstances, the contradictions are more important than destiny or fate, the passions of ambition and love are stronger than everything, and men and women are in the middle, playing their role, trying to fight the passions with their will in a political state, monarchy that is always in question. Confronted by these enacted cases, the audience, mainly standing, often noisy, can judge, admire, condemn or share with the characters, and with the other spectators, the situation, conversing, thinking about the circumstances and the story of those heroes. This is the interest and the pleasure of the Cornelian, and sometimes Racinian, tragedy.

Yet if there is absolutely no tragic in Corneille's tragedies, there is perhaps, in a sense, some with Racine, stemming from his faith. But to understand the type of tragedy the seventeenth century could propose, we have to consider tragedy's relationship with religion. We have seen that Corneille confronts his characters with themselves and with the other characters in a political situation with a corresponding love situation, and all those elements are in contradiction: the hero has to choose between his passion and his honor, his will. For Corneille it is always possible to choose the good by will, as Providence is there to help, or by interest: the structure is open, can allow sudden changes of chance, peripeteias, choices, but the idea is to show how heroes, kings, aristocrats, can fight the (human) conditions under which they exist. And there is always an opportunity to do so, with the help of Providence, or not ... God loves every man and Providence is offered to everybody till man embraces it, choosing the Good. ${ }^{20}$ The question then is to know if man chooses really the Good or if he gives the appearance of choosing it; if man is given contrition or

20 The ideology that Corneille follows is the Jesuit theory of grace called la 'grâce suffisante'. Following Thomas Aquinas's reflections, Corneille places his characters in front of the relation between grace and free will. How can the all-persuasiveness of grace, which imposes such a potent influence on the human will and elicits therefrom such good works, 
if he gets it; if the world, the political world, can be, or not, a matter for grace, or something which is beyond grace; if the king or the hero is, as every man, subjected to grace or if he is somewhere else, because of the political situation. The end of the tragedies shows that a king, a hero, a man, is always able to choose the Good, for his own sake and for the sake of the state, but Corneille does not hide that, inside the play, some disorders happened which enable the spectators to hesitate in their proper judgment about good or bad, sovereignty or tyranny, heroism or rebellion ...

At the opposite, Racine's tragedies do not suppose Providence and the protagonists are related to a sort of uncertainty with regard to their salvation. Nobody is certain of his access to salvation, but somebody can be sure that, if he fails, he will be damned. ${ }^{21}$ The tragic dramaturgy of Racine rests upon a simple principle: an inextricable and fatal situation at the heart of which contrary passions collide with each other. The result being known in advance, all of the attention bears on the logical progression of the action. Tragedy thus begins with a crisis where the hero is powerless, is condemned to unhappiness, is the victim of ravages caused by love or ambition, a passion that is total and irrepressible, and which is substituted for any other form of consciousness or interest. Grace is always uncertain, and impossible to catch. And God says nothing, is hidden as Goldman said a long time ago: evil reigns, which is terrible, and could be fascinating. In this religious sense, there is some tragic.

However in general French tragedy cannot end with a tragic situation that only engages terror and pity. To remain in a crisis, in France, is to allow the spectator to decide and to struggle with the passions represented on the stage. Tragedy cannot allow the hero to be the victim of an abstract fatality without considering that the terrible effects represented in the theater can be assigned to specific causes. It is necessary to substitute a real intelligibility in order to present a solution to the theatrical emotions. French tragedy offers a solution

reside harmoniously in the same subject with the simultaneous consent of the free will? In a way, and because the love of God is infinite, the gratia sufficiens is always open to the individual who can choose it or not. Since merely sufficient grace (gratia mere sufficiens) in its very concept contains the idea of a withholding of consent on the part of free will, and is therefore at the very outset destined to inefficiency (gratia inefficax), the question in its last analysis reduces itself to the relation between free will and efficacious grace (gratia efficax), which contains an ultimate discussion: the idea that by the efficacious grace the free will does precisely that which this grace desires should be done.

21 If Jesuitical providence can save protagonists if they have the human will to resist to their passions, this Jansenist ideology cannot provide any insurance and uses a tragic way to present heroes life. 
to the spectator, closes the plot, but in the same time, leaves something open, and allows for the spectator the freedom to oscillate and to judge.

If the spectator-subject of the seventeenth century cannot accept the ancient fatality, what he wants is to think and evaluate a consonance between the plot and the world, his world, even in extremis. If in the end, like in Elizabethan theater, a return to order is sometimes necessary, if there is often a positive lesson drawn in the last scene, the tragedy itself, during its process, leads the spectators to understand, interpret and evaluate the contradictions. However, in spite of the attempt at final resolution, tragedy has the particularity of having the crisis open for several acts, and of having asked essential and dangerous questions. The story and the plot impose it. Even if the spectators admire a pure or an heroic character at the end, the dramaturgy has opened a crisis with parricide, incest, fraternal hatred, tyranny, or destructive love-passion, and these terrible things cannot be spoken of with impunity. If the crisis is open and even if the play ends sometimes, for example with Corneille, on an optimistic note, the crisis and the transgressions resist and fascinate.

There is a shift during the first part of the seventeenth century: during the 1630s, the genre of tragedy takes its distances with the performance of actions on stage. Tragedy gets back to the declamation of a simplified poetry. The spectacular gestures and stage effects are then erased, replaced by a theatrical poem. An obvious priority is given to the text, and rhetorical, political and judicial debates between the characters hold a preeminent position. Tragi-comédies, then the comédie-ballet of Molière and the lyrical or musical tragedies of Lully will play the former hyper-spectacular role. In the same time, authors and theoreticians move away from Seneca's aesthetics, rediscover and comment upon Aristotle's Poetics, re-appreciate and adapt Sophocles' and Euripides' tragedies. But tragedy remains a genre of experimentation, and this is the interest of the tragedy: to experiment, in Corneille, with the pleasure of political, moral and amorous contradictions inside the play, and, with Racine in particular, the discovering of the dark pleasure of passion. Hesitation between consolation and indignation, admiration and repulsion, compassion (more than pity) and horror (more than terror), are the experiences that tragedy builds in its dramaturgy for the pleasure of the spectators. Such processes make for a complex pleasure: these spectators are made to experience contradictory and competing feelings, contrary passions and simultaneously (or consequently) to think and elaborate political, moral and philosophical judgments. They are taken by passions and stay in a constant distance from them. This kind of tragedy then, and in multiple ways, can be seen as an art of oscillation. 


\section{Further Reading}

Biet, Christian, Racine ou la passion des larmes (Paris: Hachette, 1997).

Biet, Christian, Moi, Pierre Corneille, auteur (Paris: Gallimard, 2006).

Biet, Christian, and Christophe, Triau, Qu'est-ce que le théâtre? (Paris: Gallimard, 2006).

Biet, Christian (ed.), Le théâtre du XVIIe siècle (Paris: L' Avant-Scène Théâtre, 2009).

Bray, René, La formation de la doctrine classique (Paris: Nizet, 1963).

Forestier, Georges, Corneille, le sens d'une dramaturgie (Paris: SESDES, 1998).

Forestier, Georges, La tragédie française: Passions tragiques et règles classiques (Paris: Armand Colin, 2010).

Goodkin, Richard E., The Tragic Middle: Racine, Aristotle, Euripides (Madison: The University of Wisconsin Press, 1991).

Goodkin, Richard E., Birth Marks: The Tragedy of Primogeniture in Pierre Corneille, Thomas Corneille and Jean Racine (Philadelphia: University of Pennsylvania Press, 2000).

Greenberg, Mitchell, Baroque Bodies: Psychoanalysis and the culture of French Absolutism (Ithaka, NY: Cornell University Press, 2001).

Greenberg Mitchell, Racine: From Ancient Myth to Tragic Modernity (Minneapolis: University of Minnesota Press, 2009).

Guyot, Sylvaine, Racine et le corps tragique (Paris: Presses Universitaires de France, 2014).

Hawcroft Michael, Word as Action: Racine, Rhetoric and Theatrical Language (Oxford: Clarendon Press, 1992.)

Louvat-Molozay, Bénédicte and Franck Salaün, Le Spectateur de théâtre à l'âge classique (XVIIU-XVIIIe siècles) (Montpellier: Editions L'Entretemps, 2008).

Louvat-Molozay, Bénédicte, L'Enfance de la tragédie (1610-1642): Pratiques tragiques françaises de Hardy à Corneille (Paris: PUPS, 2014).

Lyons, John, Kingdom of disorder: The Theory of Tragedy in Classical France (West Lafayette, IN: Purdue University Press, 1999).

Racine, Théâtre, poésie, ed. by Georges Forestier (Paris: Gallimard, 1999). 